\title{
The Role of the Academic Library in Promoting Student Engagement in Learning $^{1}$
}

\section{George D. Kuh and Robert M. Gonyea}

This study examines the nature and value of undergraduate students' experiences with the academic library. The data represent responses from more than 300,000 students between 1984 and 2002 to the College Student Experiences Questionnaire. Although library use did not appear to make independent contributions to desirable outcomes of college, such experiences were related to important educationally valuable activities. Because the emphasis a campus places on information literacy is a strong predictor of students becoming information literate, librarians should redouble their collaborative efforts to promote the value of information literacy and help create opportunities for students to evaluate the quality of the information they obtain.

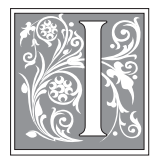

$\mathrm{t}$ is hard to imagine a college without a library. A required stop on campus tours, the library is the physical manifestation of the core values and activities of academic life. The size of the collection is used as an indicator of academic quality. Though recent years have not necessarily been kind in terms of budget support, the library's central role in the academic community is unquestioned.

It is almost heretical to ask (given the library's iconic status as a symbol of academic values), but just what does the library contribute to student learning, broadly defined? Student learning certainly is not the only relevant dimension on which to appraise the library's value and utility. Nevertheless, in the increasingly harsh light of public accountability and financial constraints, the question has never been more important or timely, nor can it be avoided. ${ }^{2}$ Three major trends demand an answer. They are (1) unfettered asynchronous access to an exponentially expanding information base; (2) a shift in the focus of colleges and universities from teaching to learning; and (3) the expectation that all university functions and programs demonstrate their effectiveness.

\section{Awash in Information}

With unlimited access to information via the Internet, the need for and practical value of a physical repository for printed and other material are less compelling today. On average, college students spend as much time on the Internet as they do studying. ${ }^{3}$ At the

George D. Kuh and Robert M. Gonyea were involved in the College Student Experiences Questionnaire Research Program, Center for Postsecondary Research, Policy, and Planning, School of Education, at Indiana University Bloomington; e-mail:kuh@indiana.edu. 
same time, the information highway introduces new challenges for librarians to meet. ${ }^{4}$ To state the obvious, not everything available electronically is valid and reliable. In the past, knowledge gatekeepers (journal editors, publishers) and librarians determined what was worth reading and collecting. Today, students make more of these judgments without assistance. Only about half of all students are confident in their ability to find good information and about the same percentage admit to having difficulty in judging the quality and accuracy of what they do find. ${ }^{5}$ For this reason, students must develop a capacity for critical discernment to judge the quality and utility of information, during and after college. The Association of College and Research Libraries (ACRL) refers to the ability to "find, retrieve, analyze, and use information" as "information literacy."

One cannot become information literate without first acquiring the foundational skills and competencies traditionally associated with general education-critical thinking and reasoning abilities, written and oral communication skills, and so forth. ${ }^{6}$ According to Shapiro and Hughes:

Information literacy should in fact be conceived more broadly as a new liberal art that extends from knowing how to use computers and access information to critical reflection on the nature of information itself, its technical infrastructure, and its social, cultural and even philosophical context and impact-as essential to the mental framework of the educated information-age citizen as the trivium of basic liberal arts (grammar, logic and rhetoric) was to the educated person in medieval society. ${ }^{7}$

To prepare librarians for the task, ACRL developed five competence standards and founded an Institute for Information Literacy (IIL) that, among other things, assists librarians in working with others in the educational community to promote and cultivate information literacy. One strategy suggested that librarians move out of the library into classrooms where they team-teach courses with faculty colleagues from various disciplines. Most of this work takes place in lower-division courses where, for better or worse, institutions emphasize general education skills and competencies. At Indiana University Purdue University Indianapolis, for example, a librarian serves on each of the four-person instructional teams (instructor, librarian, academic advisor, student mentor) that deliver the Learning Community course designed for first-year students. ${ }^{8}$ At Sonoma State University, a librarian teams with the instructor of the Freshman Interest Group seminar to increase information competence. ${ }^{9}$

\section{Embracing the Learning Paradigm}

The shift from emphasizing teaching to focusing on student learning as the primary goal of undergraduate education is gaining traction in all types of postsecondary institutions. ${ }^{10}$ Accreditors and policy makers are pushing and applauding this change in emphasis that promises to have profound effects on many aspects of academic life. The implications for the library are plain: Students' experiences with academic libraries should make direct or indirect contributions to desired outcomes of college. ${ }^{11}$ In addition to information literacy, are there other outcomes that library experiences could and should foster? The limited evidence on this point is mixed.

R. R. Powell summarized evidence that the use of the library correlated with student persistence rates and college grades. ${ }^{12}$ However, he based his conclusions on studies that, for the most part, did not control for student ability or institutional factors such as selectivity. A more recent study at Glendale Community College in California showed that students who participated in library workshops had much higher pass rates in English and ESL classes, but, again, this study did not account for student ability. ${ }^{13}$ 
Considering factors that might influence student performance, the relationships between the library and student performance are less clear. For example, J. C. Ory and L. A. Braskamp reported positive relationships between using the library and gains in critical thinking. ${ }^{14}$ Others, such as Patrick T. Terenzini and others found negative relationships between library experiences and critical thinking scores. ${ }^{15}$

The most probable explanation for the contradictory results related to critical thinking and library use is that students use library resources in different ways. To illustrate, library experiences can be divided into two types of activities. ${ }^{16}$ One is routine, but generally tentative, exploration, such as looking for information, reading assigned reference materials, and using the facility primarily to study. The second type of use-and arguably more powerful in terms of learning - is more focused exploration, analysis, and evaluation of information, driven by learner- (or collaborative work group) generated questions or, perhaps, stimulated by problems introduced by the instructor for which library resources are required to solve. Ethelene Whitmire found that the latter type of activity had a significant positive effect on student self-reported critical thinking gains. ${ }^{17}$ These effects also appeared to be independent of key student characteristics such as race and ethnicity. ${ }^{18}$

\section{Demonstrating the Library's Educational Value}

The increasing interest from all quarters in information literacy and student learning makes it difficult to ignore the heretical question posed at the outset: To what extent do libraries today contribute to information literacy and other aspects of student learning? One way to demonstrate the library's contribution is to assess whether students' experiences with the library directly or indirectly contribute to desired outcomes of college. Using the library also may have salutary effects, such as developing an appreciation of a wide range of literature or different philosophies of life. To obtain and interpret this kind of information, librarians need to understand the conditions that foster learning and how they might independently, or with others, assess the outcomes associated with library experiences.

Decades of research on college student development point to two simple propositions that account for many of the more important influences on student learning. First, the more time and energy students invest in activities related to desired outcomes of college, the more likely they are to benefit in those areas. ${ }^{19}$ Second, educationally effective institutions design experiences that channel students' energies toward educationally purposeful activities. ${ }^{20}$ Unfortunately, relatively little is known about what and how students' academic library experiences contribute to desired outcomes of college (including information literacy) or about the nature of the relationships between library use and college experiences that research studies show directly affect student learning, such as student-faculty interaction, writing activities, and so forth.

\section{Purpose}

This study examines the nature and value of students' experiences with the academic library. Its aim is to discover the unique contributions of library experiences (including contact with librarians) to the quality of effort students expend in other educationally purposeful activities, the gains they report making during college, and their overall satisfaction with the college experience. More specifically, the study attempts to answer the following questions:

1. Has student use of various library resources changed between 1984 and 2002? That is, given the availability of information via the Web and other sources, are students using the library more or less for certain reasons (for studying, for finding information)? 
2. Is frequent use of the library associated with greater gains in information literacy? What does the library contribute to other desired outcomes of college?

3. Finally, how does student use of library resources affect their engagement with effective educational practices? That is, are students who frequent the library more likely to report increased contact with faculty members inside and outside the classroom? Are they more likely to talk with peers about substantive topics such as social, political, and economic issues?

Serious conversations with other students may be an indicator of the extent to which a college's general education program animates lively discussions beyond the classroom and initiates debates on new topics. Moreover, the more engaged students are in these and other educationally purposeful activities, the more likely they are to engage fully in productive activities after college, including civic participation and so on.

\section{Methods}

\section{Instrument}

The College Student Experiences Questionnaire (CSEQ) assesses the quality of effort students devote to educationally purposeful activities. As mentioned earlier, quality of effort is the single best predictor of what students gain from college; thus, this measure also can be used to estimate the effectiveness of an institution or its component organizations (such as the library) in promoting student learning. ${ }^{21}{ }^{22}$ Overall, the CSEQ is considered to have excellent psychometric properties. ${ }^{23}$

The fourth edition of the CSEQ is made up of 166 items divided into four sections. ${ }^{24}$ The first section (18 items) asks for information about the student's background (age, year in school, major field, parents' education), how many hours per week they study, how many hours they work on and off campus, and how they are paying for their education. The second section (111 items) contains the 13 College Activities scales (including experiences with the library and computing and information technology) that measure the amount of time and energy (quality of effort) students devote to various activities. The fourth edition of the CSEQ contains both a revised library experiences scale and a computing and information technology scale that did not appear on previous editions of the instrument. The response options for these items are: $1=$ never, $2=$ occasionally, $3=$ often, and $4=$ very often. This section also includes two questions about the amount of reading and writing students do. The third section (10 items) measures student perceptions of the extent to which their institution's environment emphasizes important conditions for learning personal development, including the importance of information literacy. Student responses are scored on a 7-point scale ranging from 7 (strong emphasis) to 1 (weak emphasis). Three questions gauge student opinions about the quality of relationships with faculty members, administrative personnel, and other students on campus. Two additional questions measure student satisfaction. In the final section, students estimate the extent to which they have gained or made progress since starting college in twenty-five areas that represent desired outcomes of higher education. Response options for the "gains" items are: $1=$ very little, 2 = some, 3 = quite a bit, and 4 = very much.

\section{Samples}

To answer the three guiding research questions, the authors draw on two overlapping samples of students from the CSEQ Research Program at Indiana University Bloomington. The first sample consists of more than 300,000 students from about 300 different four-year colleges and universities who completed the second, third, and fourth editions of the CSEQ over a nineteen-year period (1984 through 2002). The second sample is composed of more than 80,000 full-time students from 131 
baccalaureate degree-granting institutions who completed the fourth edition of the CSEQ between 1998 and 2002. The background characteristics of the respondents in both samples generally mirror the population of undergraduate students attending four-year colleges and universities with a couple of exceptions. Women and white students are slightly overrepresented; and men, black, and Hispanic students are underrepresented. ${ }^{25}$

\section{Variables of Interest}

The particular variables of interest in this study are the eight items that make up the CSEQ library experiences scale (QELIB) (table 1). The scale is reliable (Table 1, Cronbach's alpha $=.80$ ), and the eight items moderately correlate with one another (ranging from .19 to .58 ; see appendix A).

\begin{tabular}{|c|c|c|}
\hline \multicolumn{3}{|c|}{$\begin{array}{c}\text { TABLE } 1 \\
\text { CSEQ Library Experiences Scale (QELIB) }\end{array}$} \\
\hline \multicolumn{3}{|c|}{$\begin{array}{l}\text { In your experience at this institution during the current school year, about how often have } \\
\text { you: }\end{array}$} \\
\hline $\begin{array}{l}\text { Item } \\
\text { name }\end{array}$ & Item label & Response set \\
\hline LIB1 & $\begin{array}{l}\text { Used the library as a quiet place to read or study materials } \\
\text { you brought with you }\end{array}$ & \multirow{8}{*}{$\begin{array}{l}1=\text { never } \\
2=\text { occasionally } \\
3=\text { often } \\
4=\text { very often }\end{array}$} \\
\hline LIB2 & Found something interesting while browsing in the library & \\
\hline LIB3 & $\begin{array}{l}\text { Asked a librarian or staff member for help in finding infor- } \\
\text { mation on some topic }\end{array}$ & \\
\hline LIB4 & $\begin{array}{l}\text { Read assigned material other than textbooks in the library } \\
\text { (reserve readings, etc.) }\end{array}$ & \\
\hline LIB5 & $\begin{array}{l}\text { Used an index or database (computer, card catalog, etc.) to } \\
\text { find material on some topic }\end{array}$ & \\
\hline LIB6 & $\begin{array}{l}\text { Developed a bibliography or reference list for a term paper } \\
\text { or other report }\end{array}$ & \\
\hline LIB7 & $\begin{array}{l}\text { Gone back to read a basic reference or document that other } \\
\text { authors referred to }\end{array}$ & \\
\hline LIB8 & $\begin{array}{l}\text { Made a judgment about the quality of information ob- } \\
\text { tained from the library, World Wide Web, or other sources }\end{array}$ & \\
\hline \multicolumn{3}{|c|}{ Cronbach's alpha $=.80$} \\
\hline
\end{tabular}

This study uses three outcome variables. The first two are composed of outcomes represented by students' responses to twenty-five questions about how much progress they have made since starting college $(1=$ very little, $2=$ some, 3 = quite a bit, $4=$ very much). The first of these is an Information Literacy Scale (INFOLIT) (table 2), which approximates the skills and competencies ACRL considers important for information literacy as reflected by student responses to six "estimate of gains" questions. The second is overall gains, or GAINSUM, the sum of responses to all twenty-five "estimate of gains" items. (See appendix B for the list of "gains" items. $)^{26}$ Because the twenty-five "gains" items encompass a holistic set of outcomes in college, GAINSUM is a measure of the student's perceived overall impact of the college experience. ${ }^{27}$ 


\begin{tabular}{|c|c|c|}
\hline \multicolumn{3}{|c|}{$\begin{array}{c}\text { TABLE } 2 \\
\text { Information Literacy Scale (INFOLIT) }\end{array}$} \\
\hline \multicolumn{3}{|c|}{$\begin{array}{l}\text { In thinking about your college or university experience up to now, to what extent do you } \\
\text { feel you have gained or made progress in the following areas? }\end{array}$} \\
\hline Item name & Item label & Response set \\
\hline GNCAREER & $\begin{array}{l}\text { Gaining a range of information that may be relevant } \\
\text { to a career }\end{array}$ & \multirow{6}{*}{$\begin{array}{l}1=\text { Very little } \\
2=\text { Some } \\
3=\text { Quite a bit } \\
4=\text { Very much }\end{array}$} \\
\hline GNGENLED & $\begin{array}{l}\text { Gaining a broad general education about different } \\
\text { fields of knowledge }\end{array}$ & \\
\hline GNCMPTS & $\begin{array}{l}\text { Using computers and other information technolo- } \\
\text { gies }\end{array}$ & \\
\hline GNANALY & Thinking analytically and logically & \\
\hline GNSYNTH & $\begin{array}{l}\text { Putting ideas together, seeing relationships, simi- } \\
\text { larities, and differences between ideas }\end{array}$ & \\
\hline GNINQ & $\begin{array}{l}\text { Learning on your own, pursuing ideas, and finding } \\
\text { information you need }\end{array}$ & \\
\hline \multicolumn{3}{|c|}{ Cronbach's alpha $=.80$} \\
\hline
\end{tabular}

The last outcome variable is satisfaction (OPINSCOR) and is composed of two CSEQ items: "How well do you like college?" and "If you could start over again, would you go to the same institution you are now attending?" (See table 3.) Student satisfaction is widely considered an important indicator of an institution's commitment to student success, and it is reasonable to expect that library experiences should contribute to this indicator. Additional statistics for the library scale and the three outcome variables appear in appendix C.

\section{TABLE 3}

Satisfaction with the College Experience Scale (OPINSCOR)

In thinking about your college or university experience up to now, to what extent do you feel you have gained or made progress in the following areas:

\begin{tabular}{|c|c|c|}
\hline Item name & Item label & Response set \\
\hline LIKECOLL & $\begin{array}{l}\text { How well do you like } \\
\text { college? }\end{array}$ & $\begin{array}{l}1=I \text { am enthusiastic about it } \\
2=\text { I like it } \\
3=I \text { am more or less neutral about it } \\
4=\text { I don't like it }\end{array}$ \\
\hline SAMECOLL & $\begin{array}{l}\text { If you could start over again, } \\
\text { would you go to the same } \\
\text { institution you are now } \\
\text { attending? }\end{array}$ & $\begin{array}{l}1=\text { Yes, definitely } \\
2=\text { Probably yes } \\
3=\text { Probably no } \\
4=\text { No, definitely }\end{array}$ \\
\hline
\end{tabular}

\section{Data Analysis}

To answer the first research question, "Has student use of the library changed over time?" the authors examined seven library experience items that remained exactly or essentially the same on the second, third, and fourth editions of the survey, spanning the years 1984 through 2002. One exception is the second and third edition question, "How often have you used a card catalogue." On the fourth edition of the CSEQ, this 
item was changed to: "How often have you used an index or database (computer, card catalog, etc.) to find material on some topic?" The authors mapped student responses to this set of library experience items by charting the combined yearly percentage of students responding "often" or "very often" to each item.

To answer the second and third questions, the authors examined the frequencies of responses to the library experiences items by gender, year in school, race, and institutional type. (See appendix D for frequency tables.) The authors also conducted an analysis of variance tests to determine whether groups differed significantly in their use of the library and in their self-reported gains. Finally, the authors conducted a series of regression analyses to examine the relationships among variables (regression tables are available from the authors).

Student characteristics and institutional characteristics can affect student collegiate experiences and outcomes. ${ }^{28}$ For example, students majoring in the humanities (which include more women than men) may be more likely to use the library facility because the nature of their academic work requires more reading and, therefore, a greater need to obtain a variety of reference material. For this reason, the authors dummy-coded gender (women as reference group) and major field (preprofessional as reference group). They also dummy-coded race and ethnicity (white as reference group) and class level (freshmen as reference group) because the success of these groups of students are of keen interest to institutions and policy makers.

The regression analyses also control for three institutional characteristics: (1) institutional type as defined by the 2000 Carnegie classification (doctoral/research-extensive universities, doctoral/research-intensive universities, master's colleges and universities, baccalaureate liberal arts colleges, and baccalaureate general colleges), (2) institutional selectivity, and (3) institutional control (public and private, with public institutions as reference group). ${ }^{29,} 30$ The Carnegie classifications were dummy-coded and entered into the models with doctoral/research-extensive universities as the reference group.

Four regression models were constructed. In the first model, the Library Experiences scale (QELIB) is the dependent variable and student and institutional characteristics are control variables. Then, selected items were added from the CSEQ College Activities scales that are conceptually associated with library use to determine which ones may account for an additional portion of variance in the library scale. These items are use of computer and information technology, course-learning activities, interactions with faculty members, writing experiences, and use of campus facilities.

The three remaining regression models examine the contribution of library experiences to three outcome measures: (1) gains in information literacy (INFOLIT), (2) overall gains in college (GAINSUM), and (3) satisfaction with the college experience (OPINSCOR). Control variables in each model include student and institutional characteristics, perceptions of the campus environment, and the academic challenge scale (table 4). The authors controlled for academic challenge because students at institutions that have high-performance expectations for academic work are more likely to use the library. Finally, the authors added the library activity items to the model to see if they would explain additional variance in the outcome measure.

In reporting the regression results, the authors will focus only on those findings that are both statistically significant and have reasonable effect sizes. That is, the objective is to identify library experiences that have practical implications as well as statistical significance. ${ }^{32}$ To do this the authors computed Y-standardized effect sizes by dividing the unstandardized coefficient by the standard deviation for the dependent variable. ${ }^{33}$ They considered effect sizes greater than $|.08|$ worthy of attention because they represent potentially important relationships between library experiences, gains from college (including information literacy), and student satisfaction. ${ }^{34}$ 


\begin{tabular}{|c|c|c|}
\hline \multicolumn{3}{|c|}{$\begin{array}{c}\text { TABLE } 4 \\
\text { Academic Challenge Items }\end{array}$} \\
\hline Item name & Item & Response set \\
\hline STUDIES4 & Hours per week on out of class academic work & $\begin{array}{l}1=U p \text { to } 5 \\
2=6-10 \\
3=11-15 \\
4=16-20 \\
5=21-25 \\
6=26-30 \\
7=30+\end{array}$ \\
\hline READTXT4 & Number of texts read & \multirow{3}{*}{$\begin{array}{l}1=\text { none } \\
2=\text { fewer than } 5 \\
3=\text { between } 5 \text { and } 10 \\
4=\text { between } 10 \text { and } 20 \\
5=\text { more than } 20\end{array}$} \\
\hline READPAK4 & Number of course packets read & \\
\hline WRITTRM4 & Number of term papers written & \\
\hline COURSE5 & Put together different facts and ideas & \multirow{5}{*}{$\begin{array}{l}1=\text { never } \\
2=\text { occasionally } \\
3=\text { often } \\
4=\text { very often }\end{array}$} \\
\hline COURSE11 & Worked on project integrating ideas & \\
\hline COURSE8 & Applied class material to other areas & \\
\hline FAC9 & Worked to meet faculty expectations & \\
\hline FAC5 & Worked harder due to instructor feedback & \\
\hline ENVSCH4 & $\begin{array}{l}\text { Emphasis on developing academic, scholarly, } \\
\text { and intellectual qualities }\end{array}$ & \multirow[t]{2}{*}{$\begin{array}{l}7=\text { strong emphasis to } \\
1=\text { weak emphasis }\end{array}$} \\
\hline ENVCRIT4 & $\begin{array}{l}\text { Emphasis on developing critical, evaluative, and } \\
\text { analytical qualities }\end{array}$ & \\
\hline \multicolumn{3}{|c|}{ Cronbach's alpha $=.74$} \\
\hline
\end{tabular}

\section{Results}

\section{Trend Analysis}

Figures 1 and 2 depict the proportions of first-year and sophomore students (combined) and juniors and seniors (combined) that responded "often" or "very often" to four selected library experiences between 1984 and 2002. These activities are: (1) used the library to read or study, (2) asked a librarian for help, (3) read in the library's reserve or reference section, and (4) used an index or database. These four experiences showed the greatest changes over the nineteen-year period, with the other four library experiences being generally stable. Because different students and institutions participate in a given year, year-to-year deviations from the trend line are common. Nevertheless, the overall multiyear trends probably reflect meaningful changes over time.

Two trends stand out. First, greater numbers of students are using indexes and databases to find information. This likely reflects the rapid and expansive deployment and use of computers and information technology during the past decade that makes more information accessible to more people as well as easier to navigate. To illustrate, in the mid-1980s, only about 30 percent of first-year and sophomore students said they frequently used indexes or databases. Beginning in the early 1990s, this percentage jumped to close to half. Juniors and seniors showed similar increases, from about 38 percent in the 1980s to over 60 percent by 2001.

The second trend is the decline in the proportion of students who use the library as a place to read or study. This is probably due to the explosion of the World Wide Web in the mid-1990s, making it possible for many students to access information and 

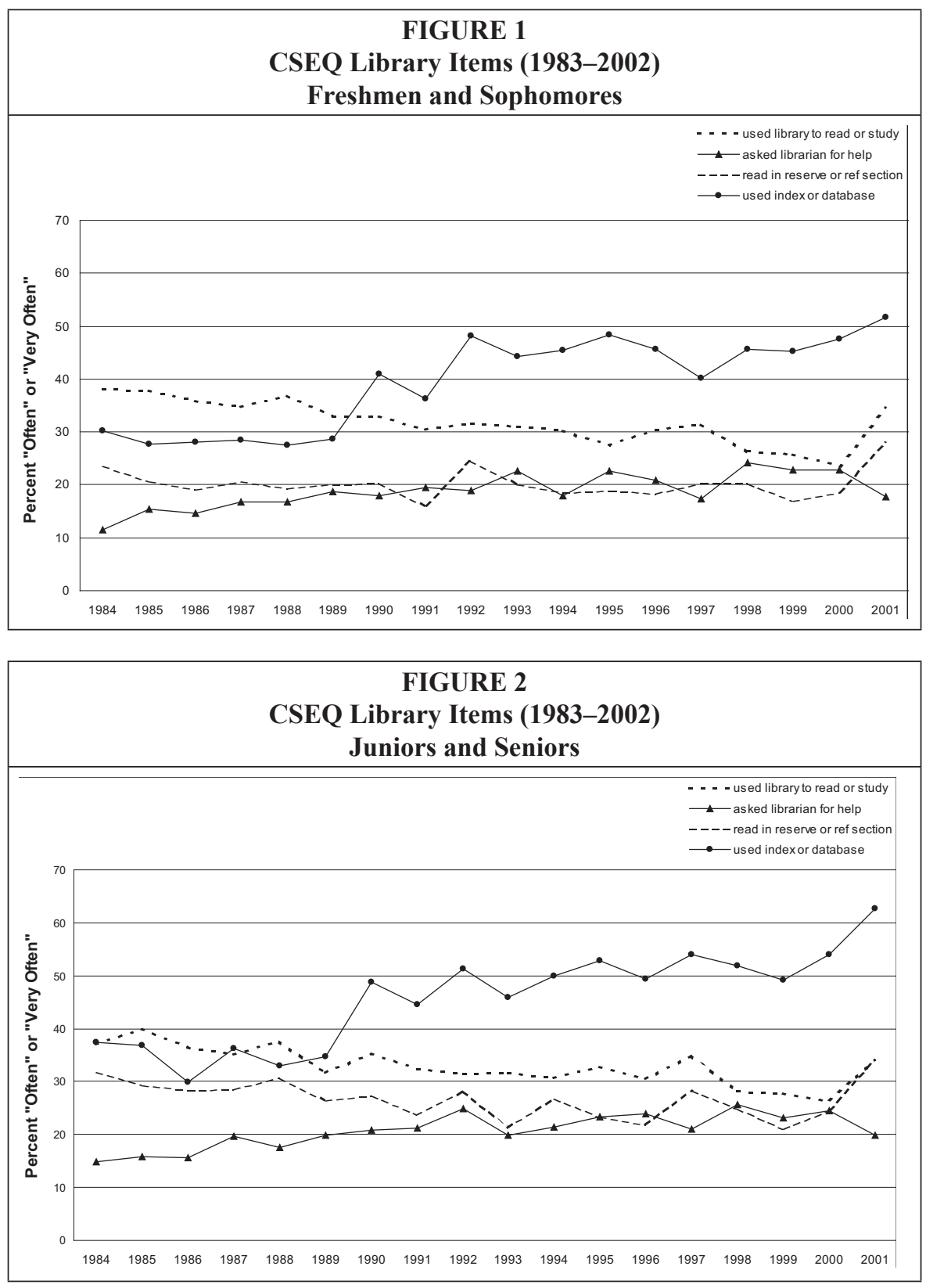

library resources online from their dorm rooms, fraternity and sorority houses, other campus locations, and off-campus residences. ${ }^{35}$ Another factor may be the availability of additional campus venues where students can do academic work, such as computer labs, academic support centers, and study lounges in campus unions or residence halls. These locations may be especially attractive to commuter students if parking near the library is problematic.

A less definitive trend is a slight increase in the number of students asking a librarian for help during the 1980s and early 1990s. Librarians about this time began to offer 
instructional workshops and guidance on how to use the Web. ${ }^{36}$ Another factor may have been the involvement of librarians in student success programs, such as orientation and first-year student seminars. This behavior varies a bit more from the mid-1990s on, perhaps because librarians were more or less involved in such efforts at the different schools participating in various years. What cannot be told from these data is whether the nature of the requests of librarians made by students changed through time. For example, are students more frequently asking librarians for technical assistance with online databases and search engines? Are students asking for assistance in finding materials contained in the library building?

\section{Frequency of Library Use}

Examination of students' library experiences shows some interesting differences by class, race, major, and institutional type (appendix D). The ANOVA tests support these differences. ${ }^{37}$ On balance, as students move through the college years, they become more information literate each year, a finding corroborated by Steve Jones. ${ }^{38}$ For example, each successive year from first-year to senior shows a significant increase in the frequency of library use. That is, more seniors frequently make judgments about information quality (43\%) compared with first-year students (34\%); fewer seniors compared with first-year students (18\% and $26 \%$, respectively) say they "never" do this.

Hispanic, Latino, and black students use library resources more frequently, whereas white students use libraries the least. Students majoring in humanities and social sciences are, as expected, the most frequent users of the library, as are students who report two or more majors. Students with undecided majors and those majoring in business, math, and science score the lowest on the library scale. Finally, students attending baccalaureate liberal arts colleges use the library more often, whereas those attending baccalaureate general colleges and doctoral/research-extensive universities do so least often. The next section discusses whether these differences hold up after controlling for student and institutional variables simultaneously.

\section{Regression Results}

The first regression model uses the library experiences scale (QELIB) as the dependent variable to answer the question, "Who uses the library most?" (See appendix E.) After controlling for student and institutional characteristics, students of color use the library more frequently compared with white students; students majoring in the humanities and preprofessional fields use the library more often than those majoring in business, math, or science. Access to computing and information technology inversely relates to library use and shows a relatively large effect size (.17); that is, students who do not have a computer where they live or work (or nearby) tend to use the library more. Perhaps for these students, the library is one place where they can use a computer that, in turn, allows them to access databases and obtain information from other libraries. At the institutional level, students at doctoral/research-extensive universities use the library less frequently compared with students attending the other four types of institutions.

Academic challenge relates positively to library use. Of the eleven academic challenge items (table 4), five have effect sizes greater than I.08।. These include three items related to course learning experiences (put together different facts and ideas, worked on projects integrating ideas from various sources, and applied class material to other areas in life) and two student-faculty interaction items (worked harder than you thought you could to meet faculty expectations and worked harder due to instructor feedback). In addition, all other items in the scale show statistically significant differences, although with smaller effect sizes. 
The results from the three regression models predicting desired college outcomesgains in information literacy, overall gains in college, and satisfaction-appear in appendix F. Taken together, these models indicate that none of the individual library activities appears to have a substantial influence on any of the three outcome variables, after controlling for student and institutional characteristics, perceptions of the environment, and academic challenge.

The outcome variable represented in the first regression is information literacy. In this model, transfer students and first-year students make the least progress in information literacy. For first-year students, this is surely due to the small amount of time they have been in college. For transfer students, the finding is more difficult to interpret and is cause for concern if this sizeable fraction of students is not gaining as much as other students in this important area. Although students majoring in math and science do not use the library as much as their peers do, they report gaining more in information literacy relative to preprofessional majors. Humanities majors gain less in information literacy (relative to preprofessional majors), after controlling for other factors. Students at doctoral/research extensive universities report the greatest gains in information literacy, followed by students at baccalaureate general colleges, doctoral/research-intensive universities, and baccalaureate liberal arts colleges. Finally, as expected, students who perceive that their institution places a strong emphasis on acquiring information literacy skills report higher gains in information literacy.

The model predicting overall gains tells a somewhat different story. Women and transfer students report making less progress during college, after controlling for other student and institutional characteristics. Black, Hispanic, and Latino students report greater gains than do white students. In terms of institutional type, students at baccalaureate liberal arts and baccalaureate general colleges report lower gains relative to students in doctoral/research-extensive universities.

The third model shows that transfer students are less satisfied with their overall college experiences, and, as expected, students with higher grades are more satisfied. Black and Asian students are also less satisfied than are white students, but Hispanic students are on par with whites in this category. In general, students at the large doctoral-extensive institutions are more satisfied with college than are students at the other four institutional types. It appears that a key to satisfaction may be the quality of relationships with other students. This item shows a large effect size (.21) even after controlling for other factors. Still, as with the previous two, this model produced no significant relationships between library experiences and satisfaction with college, after controlling for student and institutional characteristics, perceptions of the environment, and academic challenge.

In summary, frequency of library use varies depending on the type of student and the type of institution. The least frequent library users are white students, math and science majors, those who have ready access to a computer, and those who are attending doctoral-extensive universities. Those who use the library more frequently report a higher degree of academic challenge. On balance, library experiences are not directly related to information literacy, overall gains in college, or satisfaction with the college experience.

\section{Discussion}

The results of this study indicate that student use of the library has changed over time. This is not surprising given the now near-universal access college students have to computing and information technology. Nonetheless, these data corroborate anecdotal reports and other studies. ${ }^{39}$ More important, student contact with librarians has increased somewhat during this period, suggesting that librarians may be becoming 
more visible and accessible to larger numbers of students. Perhaps students need help to find good information and to make judgments about the quality of the information they do find. ${ }^{40}$ It is supported by the relatively high correlations produced in this study between "asked a librarian" and other behaviors such as "used index or database," "found something interesting while browsing," and "developed a bibliography for a term paper." At the same time, almost one-fifth of all seniors say they never made judgments about the quality of the information they obtain for use in the academic work. This is an unacceptably high number of students about to graduate from college who, by their own report, are underprepared to live and work in an information-rich world.

Smallness begets distinctiveness in American higher education. ${ }^{41}$ This appears to be the case for the library as well, as the character of experiences with academic libraries at small, academically challenging baccalaureate liberal arts colleges sets them apart from other types of institutions. For example, more students at baccalaureate liberal arts colleges $(40 \%)$ say they frequently make judgments about the quality of the material than at any other type of institution (33\% at doctoral/research-extensive universities; $37 \%$ at doctoral/research intensive universities; $34 \%$ at master's institutions, and 33\% at baccalaureate general colleges) (appendix E). In addition, library experiences at the baccalaureate liberal arts colleges strongly correlated with one another and with other educationally purposeful activities, such as working with a faculty member on research or discussing papers with faculty members. One obvious explanation for this is that because most of these institutions are residential in nature, the library is in close proximity to where students live, making access much easier. In contrast, library use is least frequent at larger doctoral/research-extensive universities. In part, this may be because of the array of alternate academic support venues such institutions provide, such as computer labs and academic skills centers. Having these options possibly mutes the impact of the academic library on many of the outcomes measures and reduces the necessity that a student must use the library for these vital academic services. In addition, research institutions are more likely to claim better wiring for technologywith broadband access to computer networks, excellent library search engines online, network access in residence hall rooms, and so on.

\section{Academic Challenge Matters}

Size and selectivity are not the only factors that influence library use. Academic challenge also is important. That is, institutions that set high standards for academic work seem to impel students to use a variety of intellectual resources actively, including the library. As a result, students who frequently use library resources are also more likely to work harder than they thought they could to meet a faculty member's expectations and in response to instructor feedback; and they are assigned projects that require integrating ideas, putting different facts and ideas together, and applying class material to other areas in life. In addition, students at academically challenging institutions are more likely to ask a librarian for help, use indexes and databases, and make thoughtful judgments about the quality of information they receive. At the same time, using the library does not appear to be associated with the amount of effort students put forth on their own in many other learning activities, such as the amount of effort they put forth in writing or the frequency with which they converse about substantive matters with peers.

\section{The Library's Contribution to Student Success}

On balance, the results of this study indicate that libraries play an important role in helping the institution achieve its academic mission. It is particularly gratifying that students of color generally use the library as much or more than do other students, 
especially black, Asian and Pacific Islander, Hispanic and Latino students. Perhaps students of color find the academic library to be a safe haven, a place that supports and nurtures academic success in collaboration with peers of the same racial and ethnic background, much in the same way the campus union provides a venue for social gatherings. If so, the library is providing a very valuable service for a subset of undergraduates that is increasing in number.

The most surprising (and mildly disappointing) finding is that library experiences do not seem to directly contribute to gains in information literacy, to what students gain overall from college, or to student satisfaction. There are three plausible explanations for this. First, the information literacy scale created from selected CSEQ items may not be a valid proxy; that is, other measures may more accurately estimate information literacy as defined by the ACRL. Second, the lack of baseline measures for information literacy and the other gains makes it difficult to draw conclusions from student self-reported estimates of their gains. ${ }^{42}$ For example, students attending different colleges or majoring in different fields may start college at various levels of information literacy. Some students who report gaining relatively little may have been fairly information literate when they started college. Other students who say they gained a good deal may have started college with a lower level of literacy. So, whereas the latter group may have, indeed, gained a substantial amount during college, their actual level of information literacy may be the same as, or even lower than, their peers who reported making less progress in the area since beginning college. This same caveat holds for the overall gains measure. Finally, as with most other desired outcomes, a variety of experiences during college, inside and outside class, contribute to gains and satisfaction, not just one type of experience. That is, critical thinking is not primarily or exclusively cultivated in the classroom or in the major field; rather, it is the product of cumulative experiences over time in a variety of venues. ${ }^{43}$ There is no reason to expect that the relationship between library experiences and gains in information literacy or other areas would be different. Indeed, the findings of this study offer no silver bullet (or single intervention) that will produce an informationliterate college graduate.

For example, students who report higher levels of information literacy were attending institutions that emphasized the importance of information literacy and encouraged students to use computers and other information resources. They also performed a good deal of reading, including some basic references that are more likely to exist either in the library or online. In addition, students who gained the most in information literacy more often made judgments about the quality of the information they obtained. In other words, students who make the greatest gains in information literacy attend institutions that communicate the importance of information literacy and practice the skills that lead to information literacy.

\section{Implications for Practice and Additional Research}

This brings us to one of the more important findings from this study: Students who perceive that their campus emphasizes information literacy gain more in this area, net of other influences. This underscores the need to collaborate with classroom instructors and student affairs professionals to deliver clear and consistent messages regarding the value of learning about various sources of information, requires evidence that students make discerning judgments about the quality of the information they use, and, equally important, gives students feedback on the quality of these judgments. Anecdotal experience suggests that students are more likely to evaluate critically the quality of sources when instructors explicitly require them to do so. ${ }^{44}$ This suggests that if institutions are serious about graduating information-literate students, they 
should require activities that give students practice and require them to demonstrate their competence in evaluating the quality of the information they use. Librarians, faculty members, and others will have to be directly involved in giving students prompt, ongoing feedback about their performance. The University of California at Berkeley is an example of this, where the teaching library and the departments of political science and sociology are designing a graduated program of instruction across the undergraduate years that will require students to use information resources. ${ }^{45}$ Librarians also might partner with student affairs staff to help them identify ways to identify students who may be struggling with using information appropriately and responsibly.

A reasonable amount of interaction with knowledgeable adults on a college campus is very important to student learning. These interactions are especially valuable when they focus on substantive or course content matters. ${ }^{46}$ Transfer students are one group of students that would benefit from more attention in this regard. At least 40 percent of seniors attending four-year colleges and universities started college at a school other than the one from which they are about to graduate. ${ }^{47}$ Yet, they are generally less engaged in educationally purposeful activities than are their native student counterparts. It is difficult to reach transfer students directly, as they are not concentrated in living units or certain courses. Perhaps librarians could collaborate with academic departments to explore ways to induce transfer students to use the library more frequently and to help them attain levels of information literacy comparable to students who start and graduate from the same college. The California State University system has recognized this need, and its twenty-three campuses are joining with community colleges as well as high schools to improve information literacy. ${ }^{48}$

Higher education needs more investigations into the library's effectiveness in promoting student learning. One fruitful line of inquiry would be to determine the kinds of student interactions with librarians beyond those represented on the CSEQ that effectively promote learning or affect other aspects of the college experience. The CSEQ does not ask about whether students made effective use of what they learned in a session focused on information literacy facilitated by a librarian; answers to this and related questions would be very instructive in terms of the library's contribution. Another instructive effort would be to determine which approaches are most effective in teaching information literacy. Are these skills and competencies best cultivated through a freestanding course, sprinkled throughout the curriculum, or learned within the context of the discipline or a specific topic? Other research indicates that students learn what they study. It would be useful to compare the information literacy levels of students at institutions that require library assignments as part of one or more courses with those that do not.

Another research question is whether student use of the library and interactions with librarians are associated with persistence and graduation, net of other factors. Previous research has suggested that library experiences relate positively to persistence and student achievement. Most of this research is dated, however, and did not employ advanced statistical methods that controlled for student ability or institutional selectivity.

A time-honored improvement strategy in higher education and other sectors is to identify high-performing organizations, find out what they do well, and adapt these promising practices for use in other settings. For example, some institutions have higherthan-predicted graduation rates and student engagement levels. ${ }^{49}$ Perhaps students at certain colleges and universities use the library more and benefit more than might be predicted, all things being equal. It would be instructive to learn more about these institutions and their libraries. 


\section{Limitations}

This study is limited in that the data are from colleges and universities that voluntarily administered the CSEQ. If data from other institutions were included, the findings might change in unknown ways. Another factor that could affect the results is whether additional student-level measures (e.g., ability, motivation) and institution-level data (e.g., resources) were included in the models. There also is the possibility that, as mentioned earlier, students use different baselines when reporting gains.${ }^{50}$ Despite these limitations, the CSEQ research program represents one of the most extensive national databases with survey information from college students related to their quality of effort and gains from college. It is one of the few multi-institution sources of information about the undergraduate experience that examines the influence of the library on information literacy and other aspects of student learning and personal development.

\section{Conclusion}

The results of this exploratory study indicate that library experiences of undergraduates positively relate to select educationally purposeful activities, such as using computing and information technology and interacting with faculty members. Those students who more frequently use the library reflect a studious work ethic and engage in academically challenging tasks that require higher-order thinking. Although certain student background characteristics (race, major, year in school, transfer status, access to computers) affect the nature and frequency of students' library activities, the library appears to be a positive learning environment for all students, especially members of historically underrepresented groups.

At the same time, library use does not appear to contribute directly to gains in information literacy and other desirable outcomes. This is not surprising, as rarely does any single experience or set of activities during college affect student learning and personal development one way or the other; rather, what is most important to college impact is the nature and breadth of a student's experiences over an extended period.

Academic librarians are well positioned to provide leadership and expertise to outcomes associated with information literacy. However, higher education institutions should not expect them to do this alone. The findings of this study indicate that it takes a whole campus to produce an information-literate college graduate. For this reason, librarians would do well to redouble their efforts to collaborate with faculty members, instructional development staff, and student affairs professionals in promoting the value of information literacy in various in-class and out-of-class activities and to provide students with as many opportunities as possible to evaluate the quality of the information they encounter, on and off the campus. 


\begin{tabular}{|l|l|l|l|l|l|l|l|l|l|}
\hline \multicolumn{7}{|c|}{ APPENDIX A } \\
\hline \multicolumn{7}{|c|}{ CSEQ Library Scale Inter-Item Correlation Coefficients* } \\
\hline LIB1 & $\begin{array}{l}\text { Used the library to } \\
\text { study }\end{array}$ & & & & & & & & \\
\hline LIB2 & $\begin{array}{l}\text { Found something } \\
\text { interesting browsing }\end{array}$ & .37 & & & & & & & \\
\hline LIB3 & $\begin{array}{l}\text { Asked a librarian/staff } \\
\text { member for help }\end{array}$ & .19 & .31 & & & & & & \\
\hline LIB4 & $\begin{array}{l}\text { Read assigned } \\
\text { material not texts }\end{array}$ & .40 & .39 & .30 & & & & & \\
\hline LIB5 & $\begin{array}{l}\text { Used index or data- } \\
\text { base to find material }\end{array}$ & .26 & .39 & .38 & .38 & & & & \\
\hline LIB6 & $\begin{array}{l}\text { Wrote bibliography } \\
\text { for a term paper }\end{array}$ & .21 & .27 & .33 & .32 & .58 & & & \\
\hline LIB7 & $\begin{array}{l}\text { Gone back to read } \\
\text { basic reference }\end{array}$ & .26 & .37 & .28 & .36 & .36 & .43 & & \\
\hline LIB8 & $\begin{array}{l}\text { Made a judgment } \\
\text { about quality of info }\end{array}$ & .21 & .31 & .23 & .27 & .42 & .44 & .39 & \\
\hline *Item-total correlations range from .40 to .62, indicating that each item contributes substantially \\
to the scale.
\end{tabular}




\begin{tabular}{|c|c|c|}
\hline \multicolumn{3}{|c|}{$\begin{array}{c}\text { APPENDIX B } \\
\text { CSEQ Gain Scales and Items* }\end{array}$} \\
\hline Category & Item name & Item label \\
\hline \multirow{6}{*}{$\begin{array}{l}\text { General } \\
\text { Education }\end{array}$} & GNARTS & Understanding and enjoyment of art, music, drama \\
\hline & GNLIT & Acquaintance with and enjoyment of literature \\
\hline & GNHIST & Knowledge of history \\
\hline & GNWORLD & Knowledge about different parts of the world and people \\
\hline & GNPHILS & Awareness of different philosophies, cultures, ways of life \\
\hline & GNGENLED & Broad general education \\
\hline \multirow{5}{*}{$\begin{array}{l}\text { Personal } \\
\text { Development }\end{array}$} & GNVALUES & Values and ethical standards \\
\hline & GNSELF & Self-understanding \\
\hline & GNOTHERS & Ability to get along with others \\
\hline & GNTEAM & Teamwork skills \\
\hline & GNHEALTH & Good health habits and physical fitness \\
\hline \multirow{3}{*}{$\begin{array}{l}\text { Science and } \\
\text { Technology }\end{array}$} & GNSCI & Science and experimentation \\
\hline & GNTECH & Science and technology developments \\
\hline & GNCONSQ & Consequences of science and technology \\
\hline \multirow{3}{*}{$\begin{array}{l}\text { Vocational } \\
\text { Preparation }\end{array}$} & GNVOC & Job or work skills \\
\hline & GNSPEC & Background for further education \\
\hline & GNCAREER & Career information \\
\hline \multirow{8}{*}{$\begin{array}{l}\text { Intellectual } \\
\text { Development }\end{array}$} & GNWRITE & Writing \\
\hline & GNSPEAK & Presenting and speaking \\
\hline & GNCOMPUT & Computers and other information technologies \\
\hline & GNANALY & Analytical and logical thinking \\
\hline & GNQUANT & Quantitative problem solving \\
\hline & GNSYNTH & Synthesis ability \\
\hline & GNINQ & Self-directed learning \\
\hline & GNADAPT & Adapting to change \\
\hline$* \mathrm{G}$ & ains items: $1=$ & $\begin{array}{l}\text { Very little, } 2=\text { Some, } 3=\text { Quite a bit, } 4=\text { Very much } \\
\text { item-total correlations range from } .39 \text { to } .68\end{array}$ \\
\hline
\end{tabular}

\begin{tabular}{|c|c|c|c|c|c|c|c|c|}
\hline \multicolumn{9}{|c|}{$\begin{array}{c}\text { APPENDIX C } \\
\text { Descriptive Statistics for Dependent Variables Used in the Study }\end{array}$} \\
\hline Measure & Valid N & Missing N & $\begin{array}{c}\% \\
\text { Missing }\end{array}$ & Mean & S.E.M. & $\begin{array}{l}\text { Std. } \\
\text { Dev. }\end{array}$ & Skewness & Kurtosis \\
\hline QELIB & 78,425 & 1,844 & $2 \%$ & 17.0 & 0.02 & 4.6 & 0.37 & 0.08 \\
\hline INFOLIT & 76,987 & 3,282 & $4 \%$ & 17.7 & 0.01 & 3.5 & -0.29 & -0.25 \\
\hline GAINSUM & 75,103 & 5,166 & $7 \%$ & 67.8 & 0.05 & 13.1 & -0.07 & -0.14 \\
\hline OPINSCOR & 78,487 & 1,782 & $2 \%$ & 6.3 & 0.01 & 1.5 & -0.76 & 0.19 \\
\hline
\end{tabular}




\begin{tabular}{|c|c|c|c|}
\hline \multicolumn{4}{|c|}{$\begin{array}{c}\text { APPENDIX D } \\
\text { Frequencies to Library Experience Items by Sex, Class, Race, } \\
\text { and Institutional Type }\end{array}$} \\
\hline \multicolumn{2}{|c|}{$\begin{array}{l}\text { Frequency of Responses to CSEQ Library Experiences } \\
\text { Items by Sex }\end{array}$} & \multirow{2}{*}{$\begin{array}{l}\text { Male } \\
\text { Col\% }\end{array}$} & \multirow{2}{*}{$\frac{\text { Female }}{\text { Col\% }}$} \\
\hline & Response Options & & \\
\hline \multirow[t]{4}{*}{ Used the library to study } & Never & 24.6 & 23.3 \\
\hline & Occasionally & 46.2 & 48.7 \\
\hline & Often & 17.5 & 16.8 \\
\hline & Very often & 11.6 & 11.2 \\
\hline \multirow{4}{*}{$\begin{array}{l}\text { Found something interesting } \\
\text { browsing }\end{array}$} & Never & 33.5 & 36.2 \\
\hline & Occasionally & 45.7 & 47.2 \\
\hline & Often & 14.7 & 11.6 \\
\hline & Very often & 6.2 & 4.9 \\
\hline \multirow{4}{*}{$\begin{array}{l}\text { Asked a librarian/staff member } \\
\text { for help }\end{array}$} & Never & 29.9 & 23.0 \\
\hline & Occasionally & 49.7 & 52.6 \\
\hline & Often & 15.6 & 18.0 \\
\hline & Very often & 4.8 & 6.4 \\
\hline \multirow[t]{4}{*}{ Read assigned material not texts } & Never & 32.5 & 31.2 \\
\hline & Occasionally & 45.1 & 44.3 \\
\hline & Often & 16.4 & 17.4 \\
\hline & Very often & 6.0 & 7.1 \\
\hline \multirow{4}{*}{$\begin{array}{l}\text { Used index or database to find } \\
\text { material }\end{array}$} & Never & 13.3 & 9.1 \\
\hline & Occasionally & 39.9 & 34.1 \\
\hline & Often & 30.0 & 33.0 \\
\hline & Very often & 16.9 & 23.8 \\
\hline \multirow{4}{*}{$\begin{array}{l}\text { Wrote bibliography for a term } \\
\text { paper }\end{array}$} & Never & 20.9 & 16.8 \\
\hline & Occasionally & 40.4 & 34.2 \\
\hline & Often & 25.8 & 28.6 \\
\hline & Very often & 13.0 & 20.5 \\
\hline \multirow[t]{4}{*}{ Gone back to read basic reference } & Never & 53.9 & 58.3 \\
\hline & Occasionally & 34.0 & 30.6 \\
\hline & Often & 8.7 & 7.6 \\
\hline & Very often & 3.4 & 3.6 \\
\hline \multirow{4}{*}{$\begin{array}{l}\text { Made a judgment about quality } \\
\text { of info. }\end{array}$} & Never & 24.3 & 22.6 \\
\hline & Occasionally & 39.5 & 41.0 \\
\hline & Often & 23.7 & 24.0 \\
\hline & Very often & 12.6 & 12.4 \\
\hline
\end{tabular}




\begin{tabular}{|c|c|c|c|c|c|}
\hline \multicolumn{6}{|c|}{$\begin{array}{l}\text { APPENDIX D } \\
\text { Frequencies to Library Experience Items by Sex, Class, Race, } \\
\text { and Institutional Type }\end{array}$} \\
\hline \multicolumn{2}{|c|}{$\begin{array}{l}\text { Frequency of Responses to CSEQ } \\
\text { Library Experiences Items by Class }\end{array}$} & \multirow{2}{*}{$\frac{\text { First-year }}{\text { Col\% }}$} & \multirow{2}{*}{$\begin{array}{c}\text { Sophomore } \\
\text { Col\% }\end{array}$} & \multirow{2}{*}{$\begin{array}{c}\text { Junior } \\
\text { Col\% }\end{array}$} & \multirow{2}{*}{$\begin{array}{c}\text { Senior } \\
\text { Col\% }\end{array}$} \\
\hline & Response Options & & & & \\
\hline \multirow{4}{*}{$\begin{array}{l}\text { Used the library to } \\
\text { study }\end{array}$} & Never & 25.5 & 21.6 & 22.6 & 23.3 \\
\hline & Occasionally & 47.8 & 47.6 & 47.0 & 48.5 \\
\hline & Often & 16.5 & 17.9 & 17.7 & 16.9 \\
\hline & Very often & 10.1 & 12.9 & 12.7 & 11.3 \\
\hline \multirow{4}{*}{$\begin{array}{l}\text { Found something } \\
\text { interesting browsing }\end{array}$} & Never & 39.2 & 34.7 & 32.1 & 29.6 \\
\hline & Occasionally & 44.9 & 46.8 & 48.6 & 48.4 \\
\hline & Often & 11.6 & 13.1 & 13.3 & 14.7 \\
\hline & Very often & 4.3 & 5.4 & 6.0 & 7.3 \\
\hline \multirow{4}{*}{$\begin{array}{l}\text { Asked a librarian/ } \\
\text { staff member for help }\end{array}$} & Never & 28.4 & 26.1 & 25.0 & 19.9 \\
\hline & Occasionally & 48.4 & 52.4 & 53.0 & 55.9 \\
\hline & Often & 17.4 & 16.1 & 16.4 & 18.0 \\
\hline & Very often & 5.8 & 5.4 & 5.7 & 6.2 \\
\hline \multirow{4}{*}{$\begin{array}{l}\text { Read assigned } \\
\text { material not texts }\end{array}$} & Never & 37.4 & 29.2 & 28.8 & 24.3 \\
\hline & Occasionally & 42.0 & 46.3 & 45.0 & 48.3 \\
\hline & Often & 15.1 & 17.3 & 18.0 & 19.9 \\
\hline & Very often & 5.5 & 7.1 & 8.2 & 7.5 \\
\hline \multirow{4}{*}{$\begin{array}{l}\text { Used index or data- } \\
\text { base to find material }\end{array}$} & Never & 12.9 & 10.2 & 9.9 & 7.3 \\
\hline & Occasionally & 37.1 & 38.7 & 35.6 & 33.0 \\
\hline & Often & 30.8 & 31.9 & 32.2 & 33.4 \\
\hline & Very often & 19.2 & 19.2 & 22.3 & 26.3 \\
\hline \multirow{4}{*}{$\begin{array}{l}\text { Wrote bibliography } \\
\text { for a term paper }\end{array}$} & Never & 20.9 & 18.4 & 17.0 & 13.9 \\
\hline & Occasionally & 35.7 & 39.8 & 37.3 & 34.7 \\
\hline & Often & 26.8 & 27.0 & 28.2 & 28.6 \\
\hline & Very often & 16.5 & 14.8 & 17.5 & 22.8 \\
\hline \multirow{4}{*}{$\begin{array}{l}\text { Gone back to read } \\
\text { basic reference }\end{array}$} & Never & 61.1 & 58.1 & 54.0 & 47.5 \\
\hline & Occasionally & 29.0 & 31.8 & 33.8 & 36.5 \\
\hline & Often & 7.2 & 7.4 & 8.1 & 10.5 \\
\hline & Very often & 2.8 & 2.8 & 4.1 & 5.5 \\
\hline \multirow{4}{*}{$\begin{array}{l}\text { Made a judgment } \\
\text { about quality of info. }\end{array}$} & Never & 25.7 & 23.7 & 21.7 & 18.7 \\
\hline & Occasionally & 40.2 & 41.5 & 40.3 & 39.9 \\
\hline & Often & 22.8 & 23.4 & 24.5 & 26.2 \\
\hline & Very often & 11.3 & 11.4 & 13.5 & 15.3 \\
\hline
\end{tabular}




\begin{tabular}{|c|c|c|c|c|c|c|}
\hline Frequer & cies to Libra & $\begin{array}{r}\text { APPE } \\
\text { ry Expe } \\
\text { nd Instit }\end{array}$ & $\begin{array}{l}\text { NDIX D } \\
\text { ience Iten } \\
\text { Itional Ty }\end{array}$ & s by Sex, & Class, Race, & \\
\hline $\begin{array}{l}\text { Frequency of Respo } \\
\text { Library Experience } \\
\text { Race and Ethnicity }\end{array}$ & $\begin{array}{l}\text { 1ses to CSEQ } \\
\text { Items by }\end{array}$ & $\begin{array}{l}\text { Asian, } \\
\text { Pacific } \\
\text { Islander }\end{array}$ & $\begin{array}{c}\text { Black, } \\
\text { African } \\
\text { American }\end{array}$ & $\begin{array}{c}\text { White, } \\
\text { Caucasian }\end{array}$ & $\begin{array}{l}\text { Mexican- } \\
\text { American, } \\
\text { Puerto Rican } \\
\text { or Other } \\
\text { Hispanic }\end{array}$ & $\begin{array}{l}\text { Other } \\
\text { Race }\end{array}$ \\
\hline & $\begin{array}{l}\text { Response } \\
\text { Options }\end{array}$ & $\mathrm{Col} \%$ & $\mathrm{Col} \%$ & $\mathrm{Col} \%$ & $\mathrm{Col} \%$ & Col\% \\
\hline Used the library & Never & 14.7 & 21.4 & 25.3 & 18.6 & 22.3 \\
\hline to study & Occasionally & 45.5 & 47.2 & 48.3 & 46.9 & 46.9 \\
\hline & Often & 21.6 & 18.2 & 16.3 & 19.3 & 17.8 \\
\hline & Very often & 18.2 & 13.2 & 10.2 & 15.2 & 13.1 \\
\hline Found some- & Never & 30.1 & 27.4 & 36.9 & 29.1 & 30.9 \\
\hline thing interesting & Occasionally & 48.7 & 46.6 & 46.5 & 44.8 & 46.7 \\
\hline & Often & 14.3 & 19.1 & 11.8 & 17.9 & 15.3 \\
\hline & Very often & 6.9 & 7.0 & 4.9 & 8.2 & 7.1 \\
\hline Asked a librarian/ & Never & 27.4 & 17.6 & 26.1 & 25.1 & 24.7 \\
\hline staff member for & Occasionally & 53.3 & 48.1 & 51.9 & 47.5 & 49.5 \\
\hline & Often & 14.7 & 23.7 & 16.7 & 19.2 & 18.1 \\
\hline & Very often & 4.6 & 10.7 & 5.3 & 8.2 & 7.6 \\
\hline Read assigned & Never & 28.7 & 28.7 & 32.4 & 29.0 & 30.7 \\
\hline material not texts & Occasionally & 46.2 & 42.9 & 44.9 & 42.4 & 43.0 \\
\hline & Often & 17.0 & 19.5 & 16.6 & 20.1 & 17.7 \\
\hline & Very often & 8.1 & 9.0 & 6.1 & 8.5 & 8.6 \\
\hline Used index or & Never & 11.7 & 10.2 & 10.6 & 10.5 & 10.9 \\
\hline database to find & Occasionally & 37.0 & 32.6 & 36.8 & 34.9 & 34.2 \\
\hline & Often & 30.8 & 31.3 & 32.0 & 31.0 & 31.3 \\
\hline & Very often & 20.5 & 25.9 & 20.6 & 23.6 & 23.6 \\
\hline Wrote bibliog- & Never & 20.2 & 18.5 & 18.0 & 18.6 & 19.4 \\
\hline raphy for a term & Occasionally & 39.9 & 33.5 & 36.6 & 35.2 & 35.3 \\
\hline & Often & 24.6 & 27.5 & 27.8 & 27.4 & 27.3 \\
\hline & Very often & 15.3 & 20.5 & 17.6 & 18.8 & 18.1 \\
\hline Gone back to & Never & 50.9 & 49.1 & 58.3 & 49.3 & 54.0 \\
\hline read basic refer- & Occasionally & 35.4 & 35.0 & 31.1 & 34.9 & 32.2 \\
\hline & Often & 9.8 & 10.9 & 7.4 & 10.3 & 9.3 \\
\hline & Very often & 3.9 & 5.0 & 3.2 & 5.5 & 4.4 \\
\hline Made a judgment & Never & 25.4 & 26.8 & 22.8 & 22.5 & 23.1 \\
\hline about quality of & Occasionally & 39.3 & 37.3 & 41.3 & 37.3 & 37.1 \\
\hline & Often & 23.7 & 22.7 & 23.8 & 25.8 & 24.2 \\
\hline & Very often & 11.6 & 13.1 & 12.1 & 14.4 & 15.6 \\
\hline
\end{tabular}




\begin{tabular}{|c|c|c|c|c|c|c|}
\hline \multicolumn{7}{|c|}{$\begin{array}{l}\text { APPENDIX D } \\
\text { Frequencies to Library Experience Items by Sex, Class, Race, } \\
\text { and Institutional Type }\end{array}$} \\
\hline \multicolumn{2}{|c|}{$\begin{array}{l}\text { Frequency of Responses to CSEQ } \\
\text { Library Experiences Items by } \\
\text { Carnegie Classification* }\end{array}$} & \multirow{2}{*}{$\begin{array}{c}\begin{array}{c}\text { Doctoral } \\
\text { Extensive }\end{array} \\
\text { Col\% }\end{array}$} & \multirow{2}{*}{$\begin{array}{c}\begin{array}{c}\text { Doctoral } \\
\text { Intensive }\end{array} \\
\text { Col\% }\end{array}$} & \multirow{2}{*}{$\begin{array}{c}\text { Master's } \\
\text { Col\% }\end{array}$} & \multirow{2}{*}{$\begin{array}{c}\begin{array}{c}\text { Liberal } \\
\text { Arts } \\
\text { Colleges }\end{array} \\
\text { Col\% }\end{array}$} & \multirow{2}{*}{$\begin{array}{r}\begin{array}{r}\text { General } \\
\text { Colleges }\end{array} \\
\text { Col\% }\end{array}$} \\
\hline & $\begin{array}{l}\text { Response } \\
\text { Options }\end{array}$ & & & & & \\
\hline \multirow{4}{*}{$\begin{array}{l}\text { Used the library to } \\
\text { study }\end{array}$} & Never & 22.9 & 24.1 & 25.5 & 14.8 & 28.9 \\
\hline & Occasionally & 47.1 & 47.4 & 48.9 & 46.3 & 48.1 \\
\hline & Often & 17.3 & 17.0 & 16.4 & 20.8 & 15.1 \\
\hline & Very often & 12.7 & 11.5 & 9.1 & 18.1 & 7.9 \\
\hline \multirow{4}{*}{$\begin{array}{l}\text { Found something } \\
\text { interesting brows- } \\
\text { ing }\end{array}$} & Never & 38.0 & 32.3 & 35.0 & 23.7 & 38.4 \\
\hline & Occasionally & 45.5 & 42.8 & 48.4 & 50.4 & 46.6 \\
\hline & Often & 11.4 & 16.0 & 12.5 & 17.4 & 11.1 \\
\hline & Very often & 5.1 & 8.9 & 4.1 & 8.6 & 3.8 \\
\hline \multirow{4}{*}{$\begin{array}{l}\text { Asked a librarian/ } \\
\text { staff member for } \\
\text { help }\end{array}$} & Never & 29.5 & 23.5 & 23.0 & 23.0 & 24.6 \\
\hline & Occasionally & 51.4 & 48.2 & 51.8 & 56.2 & 51.1 \\
\hline & Often & 14.5 & 19.5 & 19.1 & 16.1 & 18.3 \\
\hline & Very often & 4.6 & 8.8 & 6.1 & 4.7 & 6.1 \\
\hline \multirow{4}{*}{$\begin{array}{l}\text { Read assigned } \\
\text { material not texts }\end{array}$} & Never & 33.3 & 31.7 & 32.5 & 17.0 & 35.1 \\
\hline & Occasionally & 43.9 & 43.7 & 45.9 & 44.5 & 44.7 \\
\hline & Often & 16.1 & 17.4 & 16.5 & 24.6 & 15.4 \\
\hline & Very often & 6.7 & 7.2 & 5.2 & 13.9 & 4.8 \\
\hline \multirow{4}{*}{$\begin{array}{l}\text { Used index or } \\
\text { database to find } \\
\text { material }\end{array}$} & Never & 11.6 & 10.2 & 10.4 & 5.6 & 14.0 \\
\hline & Occasionally & 37.6 & 34.1 & 36.2 & 30.4 & 40.5 \\
\hline & Often & 30.8 & 33.2 & 32.7 & 33.8 & 28.8 \\
\hline & Very often & 20.1 & 22.5 & 20.8 & 30.2 & 16.7 \\
\hline \multirow{4}{*}{$\begin{array}{l}\text { Wrote bibliog- } \\
\text { raphy for a term } \\
\text { paper }\end{array}$} & Never & 20.7 & 19.3 & 17.3 & 12.0 & 16.3 \\
\hline & Occasionally & 37.9 & 35.7 & 35.9 & 33.8 & 37.5 \\
\hline & Often & 25.2 & 27.6 & 29.4 & 29.5 & 27.7 \\
\hline & Very often & 16.1 & 17.4 & 17.4 & 24.8 & 18.4 \\
\hline \multirow{4}{*}{$\begin{array}{l}\text { Gone back to read } \\
\text { basic reference }\end{array}$} & Never & 58.1 & 55.9 & 58.1 & 44.5 & 56.2 \\
\hline & Occasionally & 30.9 & 31.7 & 30.9 & 39.0 & 33.2 \\
\hline & Often & 7.6 & 8.6 & 7.8 & 10.7 & 7.4 \\
\hline & Very often & 3.4 & 3.8 & 3.1 & 5.8 & 3.2 \\
\hline \multirow{4}{*}{$\begin{array}{l}\text { Made a judgment } \\
\text { about quality of } \\
\text { info. }\end{array}$} & Never & 24.1 & 24.0 & 23.3 & 16.4 & 24.3 \\
\hline & Occasionally & 39.0 & 39.7 & 42.3 & 38.9 & 41.4 \\
\hline & Often & 23.8 & 23.9 & 23.4 & 27.1 & 23.4 \\
\hline & Very often & 13.1 & 12.4 & 11.0 & 17.6 & 10.9 \\
\hline
\end{tabular}




\begin{tabular}{|c|c|c|c|}
\hline \multicolumn{4}{|c|}{\begin{tabular}{|c|} 
APPENDIX E \\
Variables with Significant and Reasonable Effects on the \\
Library Experiences Scale
\end{tabular}} \\
\hline \multicolumn{3}{|c|}{ Independent Variables } & $\begin{array}{l}\text { Effect } \\
\text { Size* }\end{array}$ \\
\hline \multirow{16}{*}{$\begin{array}{l}\text { Student } \\
\text { Characteristics }\end{array}$} & \multirow{4}{*}{$\begin{array}{l}\text { Race and ethnicity } \\
\text { (White as reference } \\
\text { group) }\end{array}$} & Black, African American & 0.17 \\
\hline & & Asian, Pacific Islander & 0.15 \\
\hline & & Hispanic or Latino & 0.16 \\
\hline & & Other race or ethnicity & 0.09 \\
\hline & \multirow{6}{*}{$\begin{array}{l}\text { Major Categories } \\
\text { (Pre-professional as } \\
\text { reference group) }\end{array}$} & Math and Science & -0.12 \\
\hline & & Humanities & 0.08 \\
\hline & & Social Sciences & \\
\hline & & Business & -0.09 \\
\hline & & Undecided & \\
\hline & & Two or more majors & \\
\hline & \multirow{3}{*}{$\begin{array}{l}\text { Year in school } \\
\text { (First-year students as } \\
\text { reference group) }\end{array}$} & Sophomore & \\
\hline & & Junior & 0.08 \\
\hline & & Senior & 0.14 \\
\hline & \multicolumn{2}{|c|}{ Transfer status $(1=$ transfer, $0=$ non-transfer $)$} & -0.09 \\
\hline & \multicolumn{2}{|c|}{ Access to a computer $(1=$ yes, $2=$ no $)$} & 0.17 \\
\hline & \multicolumn{2}{|c|}{ Expect to enroll for an advanced degree $(1=\mathrm{yes}, 2=$ no $)$} & 0.11 \\
\hline \multirow{4}{*}{$\begin{array}{l}\text { Institutional } \\
\text { Characteristics }\end{array}$} & \multirow{4}{*}{$\begin{array}{l}\text { Carnegie classification } \\
\text { (Doctoral-Extensive as } \\
\text { reference group) }\end{array}$} & Doctoral-Intensive & 0.24 \\
\hline & & Master's & 0.18 \\
\hline & & Liberal Arts Colleges & 0.21 \\
\hline & & General Colleges & 0.10 \\
\hline \multirow{11}{*}{$\begin{array}{l}\text { Academic } \\
\text { Challenge Scale } \\
\text { Items }\end{array}$} & STUDIES & Hours out-of-class academic work & \\
\hline & READTEXT & Number of texts read & \\
\hline & READPAK & Number of course packets read & \\
\hline & WRITTRM & Number of term papers written & \\
\hline & COURSE5 & Put together different facts and ideas & 0.08 \\
\hline & COURSE11 & $\begin{array}{l}\text { Worked on project integrating ideas } \\
\text { from various sources }\end{array}$ & 0.19 \\
\hline & COURSE8 & $\begin{array}{l}\text { Applied class material to other areas } \\
\text { in life }\end{array}$ & 0.08 \\
\hline & FAC9 & $\begin{array}{l}\text { Worked harder than thought to meet } \\
\text { faculty expectations }\end{array}$ & 0.10 \\
\hline & FAC5 & $\begin{array}{l}\text { Worked harder due to instructor } \\
\text { feedback }\end{array}$ & 0.11 \\
\hline & ENVSCH & $\begin{array}{l}\text { Environmental emphasis on scholarly, } \\
\text { academic and intellectual qualities }\end{array}$ & \\
\hline & ENVCRIT & $\begin{array}{l}\text { Environmental emphasis on de- } \\
\text { veloping critical, evaluative, and } \\
\text { analytical qualities }\end{array}$ & \\
\hline
\end{tabular}


The Role of the Academic Library in Promoting Student Engagement in Learning 381

\begin{tabular}{|c|c|c|c|c|}
\hline \multicolumn{5}{|c|}{$\begin{array}{l}\text { APPENDIX F } \\
\text { Predictors of Three Outcome Variables from the CSEQ* }\end{array}$} \\
\hline \multirow[b]{2}{*}{ Category } & \multirow{2}{*}{\begin{tabular}{|l|} 
Independent Variables \\
\\
Variable \\
\end{tabular}} & \multicolumn{3}{|c|}{ Dependent Variables } \\
\hline & & $\begin{array}{c}\text { Information } \\
\text { Literacy }\end{array}$ & $\begin{array}{c}\text { Overall } \\
\text { Gains } \\
\text { Score }\end{array}$ & $\begin{array}{c}\text { Satisfaction } \\
\text { with } \\
\text { College } \\
\text { Experience }\end{array}$ \\
\hline \multirow{6}{*}{$\begin{array}{l}\text { Student } \\
\text { Characteristics }\end{array}$} & Age & & & \\
\hline & Sex $(0=$ male, $1=$ female $)$ & & -.08 & \\
\hline & Transfer Status & -.09 & -.08 & -.09 \\
\hline & Grades at this college & & & .09 \\
\hline & $\begin{array}{l}\text { Expect to enroll for an ad- } \\
\text { vanced degree }\end{array}$ & & & \\
\hline & First generation student & & & \\
\hline \multirow{4}{*}{$\begin{array}{l}\text { Race and } \\
\text { Ethnicity }\end{array}$} & Black, African American & & .11 & -.27 \\
\hline & Asian, Pacific Islander & & & -.29 \\
\hline & Hispanic or Latino & & .12 & \\
\hline & Other race or ethnicity & & & -.08 \\
\hline \multirow[t]{6}{*}{ Major Category } & Math and Science & .16 & .15 & \\
\hline & Humanities & -.09 & & \\
\hline & Social Sciences & & & \\
\hline & Business & & & \\
\hline & Undecided & & & -.15 \\
\hline & Multiple Majors & & & \\
\hline \multirow[t]{3}{*}{ Class Standing } & Sophomore & .21 & .25 & \\
\hline & Junior & .30 & .33 & \\
\hline & Senior & .34 & .39 & -.11 \\
\hline \multirow{2}{*}{$\begin{array}{l}\text { Institutional } \\
\text { Characteristics }\end{array}$} & Barron's selectivity code & & & \\
\hline & Control ( $0=$ public, $1=$ private $)$ & & & \\
\hline \multirow[t]{4}{*}{ Institution Type } & Doctoral-Intensive & -.13 & & -.14 \\
\hline & Master's I and II & -.09 & & -.20 \\
\hline & Baccalaureate Liberal Arts & -.15 & -.10 & -.23 \\
\hline & Baccalaureate General & -.11 & -.10 & -.32 \\
\hline \multirow{8}{*}{$\begin{array}{l}\text { Perceptions of } \\
\text { Environment }\end{array}$} & Env. Emphasis: Aesthetics & & & \\
\hline & Env. Emphasis: Diversity & & & \\
\hline & $\begin{array}{l}\text { Env. Emphasis: Info. literacy } \\
\text { skills }\end{array}$ & .13 & & \\
\hline & Env. Emphasis: Vocational & & & \\
\hline & $\begin{array}{l}\text { Env. Emphasis: Practical } \\
\text { courses }\end{array}$ & & & \\
\hline & Relationships: Other students & & & .21 \\
\hline & $\begin{array}{l}\text { Relationships: Administrative } \\
\text { personnel }\end{array}$ & & & \\
\hline & $\begin{array}{l}\text { Relationships: Faculty mem- } \\
\text { bers }\end{array}$ & & & \\
\hline $\begin{array}{l}\text { Academic } \\
\text { Challenge }\end{array}$ & $\begin{array}{l}\text { CSEQ Academic Challenge } \\
\text { Scale }\end{array}$ & & & \\
\hline
\end{tabular}




\begin{tabular}{|c|c|c|c|c|}
\hline \multicolumn{5}{|c|}{$\begin{array}{c}\text { APPENDIX F } \\
\text { Predictors of Three Outcome Variables from the CSEQ* }\end{array}$} \\
\hline & Independent Variables & \multicolumn{3}{|c|}{ Dependent Variables } \\
\hline \multirow{9}{*}{$\begin{array}{l}\text { Library } \\
\text { Experiences }\end{array}$} & Used the library to study & & & \\
\hline & $\begin{array}{l}\text { Found something interesting } \\
\text { browsing }\end{array}$ & & & \\
\hline & $\begin{array}{l}\text { Asked a librarian/staff } \\
\text { member for help }\end{array}$ & & & \\
\hline & $\begin{array}{l}\text { Read assigned material not } \\
\text { texts }\end{array}$ & & & \\
\hline & $\begin{array}{l}\text { Used index or database to find } \\
\text { material }\end{array}$ & & & \\
\hline & $\begin{array}{l}\text { Wrote bibliography for a term } \\
\text { paper }\end{array}$ & & & \\
\hline & $\begin{array}{l}\text { Gone back to read basic } \\
\text { reference }\end{array}$ & & & \\
\hline & $\begin{array}{l}\text { Made a judgment about } \\
\text { quality of info }\end{array}$ & & & \\
\hline & Model R2 & .39 & .44 & .31 \\
\hline
\end{tabular}

\section{Notes}

1. This paper was originally prepared for an invited session at the 2003 ACRL National Conference. The authors thank Ann Bristow, Polly D. Boruff-Jones, Ilene Rockman, and Carolyn Walters for their comments and suggestions on an earlier draft of this paper.

2. B. G. Lindauer, "Defining and Measuring the Library's Impact on Campuswide Outcomes," College and Research Libraries 59, no. 6 (1998); Measuring Up, Measuring Up 2002: The State-by-State Report Card for Higher Education (San Jose, Calif.: National Center for Public Policy and Higher Education, 2002).

3. Steve Jones, The Internet Goes to College: How Students Are Living in the Future with Today's Technology (Washington, D.C.: Pew Internet \& American Life Project, 2002).

4. K. Dunn, "Assessing Student Information Literacy Skills in the California State University: A Progress Report," Journal of Academic Librarianship 28, no. 1/2 (2002); I. F. Rockman and Gordon W. Smith, "A Multi-dimensional Project to Assess Student Information Competence Skills," paper presented at the E-Learn Conference, Montreal, 2002.

5. National Center for Postsecondary Improvement, "The Landscape: A Report to Stakeholders on the Condition and Effectiveness of Postsecondary Education," Change 33, no. 3 (2001); Outsell, Managing Online Information to Maximize Corporate Intranet ROI (2001) [cited July 2001]). Available online from http://w.moreover.com/.

6. Lindauer, "Defining and Measuring the Library's Impact on Campuswide Outcomes."

7. J. J. Shapiro and S. K. Hughes, "Information Literacy as a Liberal Art: Enlightenment Proposals for a New Curriculum," Educom Review 31, no. 2 (1996): 2.

8. P. Boruff-Jones, personal communication, November 2002.

9. K. Brodsky and S. Toczyski, "Information Competence in the Freshman Interest Group at Sonoma State University," paper presented at the First Year Experience Conference, Orlando, 2002.

10. Robert B. Barr, and John Tagg, "From Teaching to Learning: A New Paradigm for Undergraduate Education," Change 27 (Nov. /Dec. 1995); John Tagg, The Learning Paradigm College (Bolton, Mass.: Anker, 2003).

11. Lindauer, "Defining and Measuring the Library's Impact on Campuswide Outcomes"; R. A. Wolff, "Rethinking Library Self-studies and Accreditation Visits," in The Challenge and Practice of Academic Accreditation: A Sourcebook for Library Administration, ed. E. D. Garten (Westport, Conn.: Greenwood, 1994).

12. R. R. Powell, "Impact Assessment of University Libraries," Library and Information Science 
Research 14 (1992).

13. Glendale Community College, "Information Competency Improves Grades" (2001).

14. J. C. Ory and L. A. Braskamp, "Involvement and Growth of Students in Three Academic Programs," Research in Higher Education 28 (1988).

15. Patrick T. Terenzini, "Influences Affecting the Development of Students' Critical Thinking Skills," Research in Higher Education 36, no. 1 (1995); Patrick T. Terenzini, et al., "First-generation College Students: Characteristics, Experiences, and Cognitive Development," Research in Higher Education 37, no. 1 (1996).

16. C. Robert Pace, Measuring the Quality of College Student Experiences. An Account of the Development and Use of the College Student Experiences Questionnaire (Los Angeles: Higher Education Research Institute, 1984).

17. Ethelene Whitmire, "Development of Critical Thinking Skills: An Analysis of Academic Library Experiences and Other Measures," College and University Research Libraries 59, no. 3 (1998).

18. - - - "Racial Differences in the Academic Library Experiences of Undergraduates," Journal of Academic Librarianship 25, no. 1 (1999).

19. Alexander W. Astin, "Student Involvement: A Developmental Theory for Higher Education," Journal of College Student Personnel 25 (1984); Ernest T. Pascarella and Patrick T. Terenzini, How College Affects Students, The Jossey-Bass Higher and Adult Education Series (San Francisco: JosseyBass, 1991).

20. George D. Kuh, J. H. Schuh, E. J. Whitt, and associates, Involving Colleges: Successful Approaches to Fostering Student Learning and Development outside the Classroom (San Francisco: Jossey Bass, 1991); Roy Romer, Making Quality Count in Undergraduate Education (Denver, Colo.: Education Commission of the States, 1995).

21. Pace, Measuring the Quality of College Student Experiences.

22. George D. Kuh, "Assessing What Really Matters to Student Learning: Inside the National Survey of Student Engagement," Change 33, no. 3 (2001).

23. Peter T. Ewell, and Dennis P. Jones, Indicators of "Good Practice" in Undergraduate Education: A Handbook for Development and Implementation (Boulder, Colo.: National Center for Higher Education Management Systems, 1996); Robert M. Gonyea, Kelly Kish, George D. Kuh, Richard Muthiah, and Auden Thomas CSEQ: Norms for the Fourth Edition (Bloomington, Ind.: Indiana University Center for Postsecondary Research, Policy, and Planning, 2003).

24. Robert C. Pace, and George D. Kuh, College Student Experiences Questionnaire (fourth edition) (Bloomington, Ind.: Center for Postsecondary Research and Planning, 1998).

25. The respondents in the first sample who completed the CSEQ between 1984 and 2002 include 60 percent women; 80 percent are white, 6 percent black, 3 percent Hispanic, 6 percent Asian, and 4 percent other race or ethnicity. First-year students total 35 percent, sophomores 21 percent, juniors 17 percent, and seniors 26 percent. Of the respondents in the second sample who completed the fourth edition of the CSEQ, 61 percent were women and 77 percent were white, 8 percent Asian or Pacific Islander, 5 percent black, 3 percent Mexican-American, Puerto Rican, or other Hispanic, 1 percent American Indian, 3 percent multiracial, and 3 percent other race or ethnic identity. Approximately 43 percent were first-year students, 20 percent sophomores, 17 percent juniors, and 20 percent seniors. About 20 percent were majoring in a preprofessional program (e.g., agriculture, education, communications, and health-related fields); 11 percent in social sciences (e.g., multidisciplinary studies, sociology, and public administration); 16 percent in mathematics, science, or related area (e.g., computer science and engineering); 8 percent in the humanities (e.g., ethnic studies, foreign languages, history, and visual and performing arts); and 15 percent in business. Four percent were undecided as to major field, and 21 percent had two or more majors. In terms of institutional type, 38 percent were from twenty-nine doctoral/research-extensive universities, 13 percent from seventeen doctoral/research-intensive universities, 33 percent from fortyone masters' colleges and universities, 8 percent from twenty-one baccalaureate liberal colleges, and 9 percent from twenty-three baccalaureate general colleges; Carnegie Foundation for the Advancement of Teaching, Carnegie Classification of Institutions of Higher Education, 2000 edition (Menlo Park, Calif.: Carnegie Foundation for the Advancement of Teaching, 2000); Robert M. Gonyea, Kelly Kish, George D. Kuh, Richard Muthiah, and Auden Thomas CSEQ: Norms for the Fourth Edition (Bloomington, Ind.: Indiana University Center for Postsecondary Research, Policy, and Planning, 2003).

26. George D. Kuh, Nick Vesper, Mark R. Connolly, and C. Robert Pace, "College Student Experiences Questionnaire: Revised Norms for the Third Edition," (Bloomington, Ind.: Center for Postsecondary Research and Planning, Indiana University, 1997).

27. Note that INFOLIT is a subset of GAINSUM.

28. Pascarella and Terenzini, How College Affects Students.

29. Carnegie Foundation for the Advancement of Teaching, Carnegie Classification of Institutions of Higher Education.

30. Barron's Profiles of American Colleges, 23rd ed. (Hauppauge, N.Y.: Barron's Educational 
Series, 1998).

31. Response values on items appended by a ' 4 ' were mathematically collapsed to four-point range, giving all items an equal portion of the total scale score.

32. Jacob Cohen, Statistical Power Analysis for the Behavioral Sciences, 2nd ed. (Hillsdale, N.J.: L. Erlbaum Associates, 1988).

33. R. Light and D. Pillemer, "Numbers and Narrative: Combining Their Strengths in Research Reviews," Harvard Educational Review (1982).

34. The expression " $|.08|$ " should be read "the absolute value of .08."

35. I. Rockman, personal communication, December 19, 2002.

36. Ibid.

37. ANOVA results are not reported in this paper but are available from the authors.

38. Jones, The Internet Goes to College.

39. Ibid.

40. Dunn, "Assessing Student Information Literacy Skills in the California State University"; Rockman and Smith, "A Multi-dimensional Project to Assess Student Information Competence Skills."

41. B. Clark, "The Organizational Saga in Higher Education," in ASHE Reader in Organization and Governance in Higher Education, ed. R. Birnbaum (Washington, D.C.: Association for the Study of Higher Education, 1972); George D. Kuh and Elizabeth J. Whitt, The Invisible Tapestry: Culture in American Colleges and Universities, ed. J. D. Fife ASHE-ERIC Higher Education Report No. 1 (Washington, D.C.: Association for the Student of Higher Education, 1988); B. K. Townsend, L. J. Newell, and M. D. Wiese, Creating Distinctiveness: Lessons from Uncommon Colleges and Universities, AAHE-ERIC/Higher Education Report, no. 6 (Washington, D.C.: The George Washington University, School of Education and Human Development, 1992).

42. Ernest Pascarella, "Using Student Self-reported Gains to Estimate College Impact: A Cautionary Tale," Journal of College Student Development 42 (2001).

43. Pascarella and Terenzini, How College Affects Students.

44. Carolyn Walters, personal communication, December 22, 2002.

45. P. D. Maughan, Information Literacy Survey (Berkeley: University of California, Berkeley Library, 2002).

46. George D. Kuh, and Shouping Hu, "The Effects of Student-Faculty Interaction in the 1990s," Review of Higher Education 24, no. 3 (2001).

47. George D. Kuh, "What We're Learning about Student Engagement from NSSE," Change 35, no. 2 (2003).

48. Dunn, "Assessing Student Information Literacy Skills in the California State University."

49. Kuh, "What We're Learning about Student Engagement from NSSE."

50. Pascarella, "Using Student Self-reported Gains to Estimate College Impact."

\section{References}

Astin, Alexander W. 1984. "Student Involvement: A Developmental Theory for Higher Education.” Journal of College Student Personnel 25: 297-308.

Barr, Robert B., and John Tagg. 1995. "From Teaching to Learning: A New Paradigm for Undergraduate Education." Change 27 (November/December): 13-25.

Barron's profiles of American colleges. 23rd ed. 1998. Hauppauge, N.Y.: Barron's Educational Series.

Brodsky, K., and S. Toczyski. 2002. "Information Competence in the Freshman Interest Group at Sonoma State University." Paper presented at the First Year Experience Conference, Orlando, Fla.

Carnegie Foundation for the Advancement of Teaching. 2000. Carnegie Classification of Institutions of Higher Education, 2000 edition. Menlo Park, Calif.: Carnegie Foundation for the Advancement of Teaching.

Clark, B. 1972. "The Organizational Saga in Higher Education." In ASHE Reader in Organization and Governance in Higher Education, ed. E. Birnbaum. Washington, D.C.: Association for the Study of Higher Education.

Cohen, Jacob. 1988. Statistical Power Analysis for the Behavioral Sciences. 2nd ed. Hillsdale, N.J.: L. Erlbaum Associates.

Dunn, K. 2002. “Assessing Student Information Literacy Skills in the California State University: A Progress Report." Journal of Academic Librarianship 28 (1/2): 26-35.

Ewell, Peter T., and Dennis P. Jones. 1996. Indicators of "Good Practice" in Undergraduate Education: A Handbook for Development and Implementation. Boulder, Colo.: National Center for Higher Education Management Systems.

Glendale Community College. 2001. "Information Competency Improves Grades."

Gonyea, Robert M., Kelly Kish, George D. Kuh, Richard Muthiah, and Auden Thomas. 2003. CSEQ: Norms for the Fourth Edition. Bloomington, Ind.: Indiana University Center for Postsecondary Research, Policy, and Planning. 
Jones, Steve. 2002. The Internet Goes to College: How Students Are Living in the Future with Today's Technology. Washington, D.C.: Pew Internet \& American Life Project.

Kuh, G. D. 2003. "What We're Learning about Student Engagement from NSSE." Change 35(2).

Kuh, George D. 2001. Assessing What Really Matters to Student Learning: Inside the National Survey of Student Engagement." Change 33(3): 10-17, 66.

Kuh, George D., and Shouping Hu. 2001. "The Effects of Student-Faculty Interaction in the 1990s." Review of Higher Education 24(3): 309-32.

Kuh, George D., J. H. Schuh, E. J. Whitt, and Associates. 1991. Involving Colleges: Successful Approaches to Fostering Student Learning and Development outside the Classroom. San Francisco: Jossey Bass.

Kuh, George D., Nick Vesper, Mark R. Connolly, and C. Robert Pace. 1997. College Student Experiences Questionnaire: Revised Norms for the Third Edition. Bloomington, Ind.: Center for Postsecondary Research and Planning, Indiana University.

Kuh, George D., and Elizabeth J. Whitt. 1988. The Invisible Tapestry: Culture in American Colleges and Universities, ed. J. D. Fife. ASHE-ERIC Higher Education Report No 1. Washington, D.C.: Association for the Student of Higher Education.

Light, R., and D. Pillemer. 1982. "Numbers and Narrative: Combining Their Strengths in Research Reviews." Harvard Educational Review (1982): 1-26.

Lindauer, B.G. 1998. "Defining and Measuring the Library's Impact on Campuswide Outcomes." College and Research Libraries 59(6): 546-63.

Maughan, P. D. 2002. Information Literacy Survey. Berkeley: University of California, Berkeley Library.

Measuring Up. 2002. Measuring Up 2002: The State-by-State Report Card for Higher Education. San Jose, Calif.: National Center for Public Policy and Higher Education.

National Center for Postsecondary Improvement. 2001. “The Landscape: A Report to Stakeholders on the Condition and Effectiveness of Postsecondary Education." Change 33(3): 27-42.

Ory, J. C., and L. A. Braskamp. 1988. "Involvement and Growth of Students in Three Academic Programs." Research in Higher Education 28: 116-29.

Outsell. 2001. Managing Online Information to Maximize Corporate Intranet ROI [cited July 2001]. Available online from http://w.moreover.com/.

Pace, C. Robert. 1984. Measuring the Quality of College Student Experiences. An Account of the Development and Use of the College Student Experiences Questionnaire. Los Angeles: Higher Education Research Institute.

Pace, C. Robert, and George D. Kuh. 1998. College Student Experiences Questionnaire (fourth edition). Bloomington, Ind: Center for Postsecondary Research and Planning.

Pascarella, Ernest. 2001. Using Student Self-reported Gains to Estimate College Impact: A Cautionary Tale." Journal of College Student Development 42: 488-92.

Pascarella, Ernest T., and Patrick T. Terenzini. 1991. How College Affects Students, The Jossey-Bass Higher and Adult Education Series. San Francisco: Jossey-Bass.

Powell, R. R. 1992. "Impact Assessment of University Libraries." Library and Information Science Research 14: 254.

Rockman, I. F., and Gordon W. Smith. 2002. "A Multi-dimensional Project to Assess Student Information Competence Skills." Paper presented at the E-Learn Conference, Montreal.

Romer, Roy. 1995. Making Quality Count in Undergraduate Education. Denver, Colo.: Education Commission of the States.

Shapiro, J. J., and S. K. Hughes. 1996. "Information Literacy as a Liberal Art: Enlightenment Proposals for a New Curriculum." Educom Review 31(2): 31-35.

Tagg, John. 2003. The Learning Paradigm College. Bolton, Mass.: Anker.

Terenzini, Patrick T. 1995. "Influences Affecting the Development of Students' Critical Thinking Skills." Research in Higher Education 36(1): 23-39.

Terenzini, Patrick T., et al. 1996. "First-generation College Students: Characteristics, Experiences, and Cognitive Development." Research in Higher Education 37(1): 1-22.

Townsend, B. K., L. J. Newell, and M. D. Wiese. 1992. Creating Distinctiveness: Lessons from Uncommon Colleges and Universities, AAHE-ERIC/Higher Education Report, No. 6. Washington, D.C.: The George Washington University, School of Education and Human Development.

Whitmire, Ethelene. 1998. "Development of Critical Thinking Skills: An Analysis of Academic Library Experiences and Other Measures." College and University Research Libraries 59(3): 266-73.

- - . 1999. "Racial Differences in the Academic Library Experiences of Undergraduates." Journal of Academic Librarianship 25(1): 33-37.

Wolff, R. A. 1994. "Rethinking Library Self-studies and Accreditation Visits." In The Challenge and Practice of Academic Accreditation: A Sourcebook for Library Administration, ed. E. D. Garten. Westport, Conn.: Greenwood. 